\title{
Penerapan Metode SWOT dalam Peningkatan Kapasitas Multisektoral Masyarakat Desa Lifofa Kabupaten Tidore Kepulauan
}

\author{
Muhammad Sakti Garwan \\ Institut Agama Islam Negeri Ternate \\ m.saktigarwan10@gmail.com
}

Naskah diterima: 3 Desember 2019| Naskah disetujui: 17 Januari 2020

\begin{abstract}
:
This paper describes the community service activities with cross-scientific and sectoral approaches using the SWOT method at certain times and regions, with the aim of providing several aspects, including education, social, religious, and health. Through this community service program it is expected that students can optimize a family or household in building their personality into a prosperous, independent, religious family that is able to face the challenges of a better future.
\end{abstract}

Keywords: SWOT Method, Education, Social, Health, Religion, Lifofa Village

\begin{abstract}
Abstrak:
Tulisan ini mendesripsikan tentang kegiatan pengabdian kepada masyarakat dengan pendekatan lintas keilmuan dan sektoral pada waktu dan daerah tertentu menggunakan metode SWOT, dengan tujuan memberikan beberapa aspek, diantaranya pendidikan, sosial, keagamaan, dan kesehatan. Melalui program pengabdian ini pemberdayaan masyarakat ini diharapkan mahasiswa bisa mengoptimalisasikan suatu keluarga dalam membangun kepribadiannya menjadi keluarga yang sejahtera, mandiri, agamis yang mampu menghadapi tantangan masa depan yang lebih baik.
\end{abstract}

Kata Kunci: Metode SWOT, Pendidikan, Sosial, Kesehatan, Keagamaan, Desa Lifofa

\section{Pendahuluan}

Pengabdian kepada masyarakat oleh mahasiswa yang diselenggarakan oleh Institut Agama Islam Negeri Ternate mempunyai empat kelompok sasaran, yaitu mahasiswa, masyarakat, pemerintah daerah, dan perguruan tinggi. Bagi mahasiswa, Kuliah Kerja Lapangan Integratif mempunyai sasaran untuk membina mahasiswa agar menjadi motivator dan inovator. Sementara bagi masyarakat dan Pemerintah Daerah (Pemda), mempunyai sasaran untuk memperoleh bantuan pemikiran, tenaga, serta IPTEK dalam merencanakan dan melaksanakan pembangunan. Perguruan 
tinggi mempunyai sasaran untuk memperoleh umpan balik sebagai hasil pengintegrasian mahasiswa dalam masyarakat, sehingga kurikulum perguruan tinggi dapat disesuaikan dengan kondisi masyarakat yang diwakili oleh PEMDA terkait. Adapun bentuk pengabdian berupa kegiatan fisik maupun non-fisik yang bersentuhan langsung dengan masyarakat sesuai dengan program dari Perguruan Tinggi maupun Pemerintah Daerah.

Tujuan dilaksanakannya pengabdian ini dapat dibagi menjadi dua, yakni, tujuan umum, pengabdian mahasiswa kepada masyarakat agar mampu memahami masalah dan kebutuhan serta memberikan solusi terhadap masalah yang dihadapi oleh masyarakat. Selain itu mahasiswa mampu membaca keadaan desa dari apa yang mereka buat, seperti pembuatan profil desa, sosialisasi kependudukan dan kesehatan reproduksi serta pembuatan rumah sosialisasi. Sedangkan tujuan khusus, yaitu mengimplementasikan ilmu pengetahuannya selama menempuh pendidikan di perguruan tinggi dan dituangkan dalam bentuk nyata kepada masyarakat sehingga bisa membantu masyarakat. Pengabdian yang dilakukan ini dalam bentuk program fisik dan non fisik. Adapun sasarannya adalah masyarakat desa Lifofa, baik dari kalangan pemuda dan pemudi, anak-anak sekolah, serta para santri yang ada di sana.

Program pengabdian harus dapat memberikan manfaat terhadap masyarakat, yakni dengan memberikan solusi pada permasalahan-permasalahan yang dihadapi. Dalam observasi awal yang dilakukan penulis, terdapat beberapa masalah awal yang terdapat di masyarakat, yakni; 1) masyarakat yang tidak peduli terhadap pendidikan anaknya sehingga masih ada anak-anak usia sekolah yang tidak bersekolah; 2) kurangnya dalam mempelajari keagamaan seperti membaca dan menulis al-Qur'an; 3) kurangnya pemahaman akan pentingnya kesehatan lingkungan padahal lingkungan desa Lifofa masih sangat asri alamnya; 4) perlunya pendampingan pada guru-guru di tingkat SD, SMP, dan SMA; dan 5) keadaan posyandu dan kantor BKKBN yang kurang lengkap dan tidak memadai. Berdasarkan permasalahan tersebut, maka langkah awal pengabdian sebagai penggerakan terhadap masyarakat adalah mengembangkan dan meningkatkan segala aktivitas, terutama dari sektor sosial, kesehatan dan pendidikan masyarakat.

\section{Metode Pelaksanaan}

Dalam menunjang kegiatan pengabdian, penulis menggunakan beberapa tahapan dan metode yang mendukung pelaksanaan kegiatan. Adapun tahapan dan metodenya adalah sebagai berikut:

1. Metode pengumpulan data. Digunakan untuk mengumpulkan data-data mengenai kegiatan yang sudah dan akan dilakukan pada masyarakat lingkungan serta permasalahanpermasalahan dilingkungan masyarakat yang belum terselesaikan. 
2. Menentukan tema kegiatan yang akan diberikan. Berdasarkan atas apa yang telah dilakukan dalam survei yang diuraikan secara rinci pada latar belakang sehingga tema kegiatan dapat segera ditentukan.

3. Mencari studi pustaka dengan pengumpulan data referensi dari berbagai jenis sumber keilmuan yang menunjang permasalahan yang sedang dicarikan solusinya.

4. Membuat materi penyuluhan atau pelatihan berdasarkan studi pustaka yang telah dilakukan.

5. Menyajikan penyuluhan atau pelatihan dengan metode ceramah dan praktek langsung akan materi tersebut.

Dari beberapa langkah ini kemudian penulis gunakan analisis SWOT sebagai metode perencanaan strategis untuk mengevaluasi kekuatan (strengths), kelemahan (weaknesses), peluang (opportunities), dan ancaman (threats) dalam melihat realitas sosial yang berkaitan dengan kegiatan pengabdian di Desa Lifofa. Tujuan diterapkannya metode ini di desa Lifofa adalah untuk membenahi kebutuhan masyarakat serta membimbing, mengayomi, dan mengarahkan, sesuai dengan potensi sumber daya manusia (SDM) yang ada di desa tersebut untuk bergerak maju menjadi lebih baik di seluruh aspek. Sehingga metode ini dianggap perlu digunakan untuk menggambarkan situasi yang sedang dihadapi oleh masayarakat dan menyelesaikan problem dalam situasi tersebut. Sebagaimana analisa susunan Afrillita (2013) yang terbagi atas empat komponen dasar yaitu :

1. $\mathrm{S}=$ Strength adalah situasi atau kondisi yang merupakan kekuatan dari organisasi atau program pada saat ini.

2. $\mathrm{W}=$ Weakness adalah kondisi yang merupakan kelemahan dari organisasi atau program pada saat ini.

3. $\mathrm{O}=$ Opportunity adalah situasi atau kondisi yang merupakan peluang diluar organisasi dan memberikan peluang berkembang organisasi di masa depan.

4. $\mathrm{T}=$ Threat adalah situasi yang merupakan ancaman bagi organisasi yang datang dari luar organisasi dan dapat mengancam eksistensi organisasi di masa depan. (Rangkuti, 2003) 
Berikut analisa permasalahan lokasi pengabdian di Desa Lifofa tahun 2018 berdasarkan Analisa SWOT.

1. Strengths (Kekuatan)

a) Motivasi penulis dan masyarakat yang sangat tinggi sehingga memungkinkan untuk tercapainya seluruh kegiatan pengabdian

b) Keaktifan serta kerja sama antara sesama masyarakat dapat membantu dalam pelaksanaan kegiatan

c) Adanya masyarakat yang juga pernah mahasiswa sehingga dapat membantu beberapa program kerja yang dilakukan, dalam disiplin ilmu sesuai dengan bidang dan keahlian ilmu yang didalami.

d) Bantuan dan bimbingan yang penuh dari dosen pembimbing lapangan maupun dari berbagai pihak pemerintah Desa Lifofa

2. Weaknesses (Kelemahan)

a) Jumlah keaktifan masyarakat yang kurang

b) Kehadiran masyarakat yang tidak tepat waktu pada saat pelaksanaan kegiatan sehingga dapat memperlambat kinerja saat pelaksanaan kegiatan

3. Opportunities (Peluang)

a) Memanfaatkan warga sekitar lokasi yang berkediaman tidak jauh untuk mendapatkan alat dan bahan yang dipergunakan ketika pelaksanaan program kerja menjadikan kediaman warga sebagai tempat untuk beristrahat.

b) Adanya masyarakat dengan latar belakang pernah menjadi mahasiswa dari berbagai program studi yang melaksanakan dan menjalankan program kerja sesuai dengan ilmu yang di dalami selama perkuliahan sehingga program kerja yang dilakukan dapat berjalan sesuai dengan diharapkan.

\section{Threaths (Ancaman)}

a) Kurangnya dana sehingga dapat menghambat proses kegiatan

Untuk memecahkan masalah yang terjadi di lapangan menggunakan dua metode pemecahan masalah yaitu: 
1. Metode Diskusi. Metode ini adalah salah satu alternatif dalam menyelesaikan permasalahan kelompok yaitu dengan cara musyawarah jika tidak bisa musyawarah mufakat maka diambil suara terbanyak atau biasanya disebut dengan voting.

2. Pengembangan Ide. Dalam metode pengembangan ide lebih menggunakan alternatif curah pendapat, dimana pemecahan kelompok untuk berpendapat, dengan cara memberi kesempatan bagi anggota kelompok untuk berpendapat dalam musyawarah untuk memecahkan masalah.

3. Solusi. Dalam metode diskusi sangat diperlukan musyawarah untuk menyelesaikan permasalahan yang terjadi, dalam metode ini ditelusuri pokok permasalahan yang timbul kemudian didiskusikan permasalahan yang ada dengan cara mengembangkan ide serta saran dari anggota kelompok untuk mendapatkan jalan keluar dalam hal mengenai masalah yang timbul (Hunger, 2003).

\section{Profil Desa Lifofa}
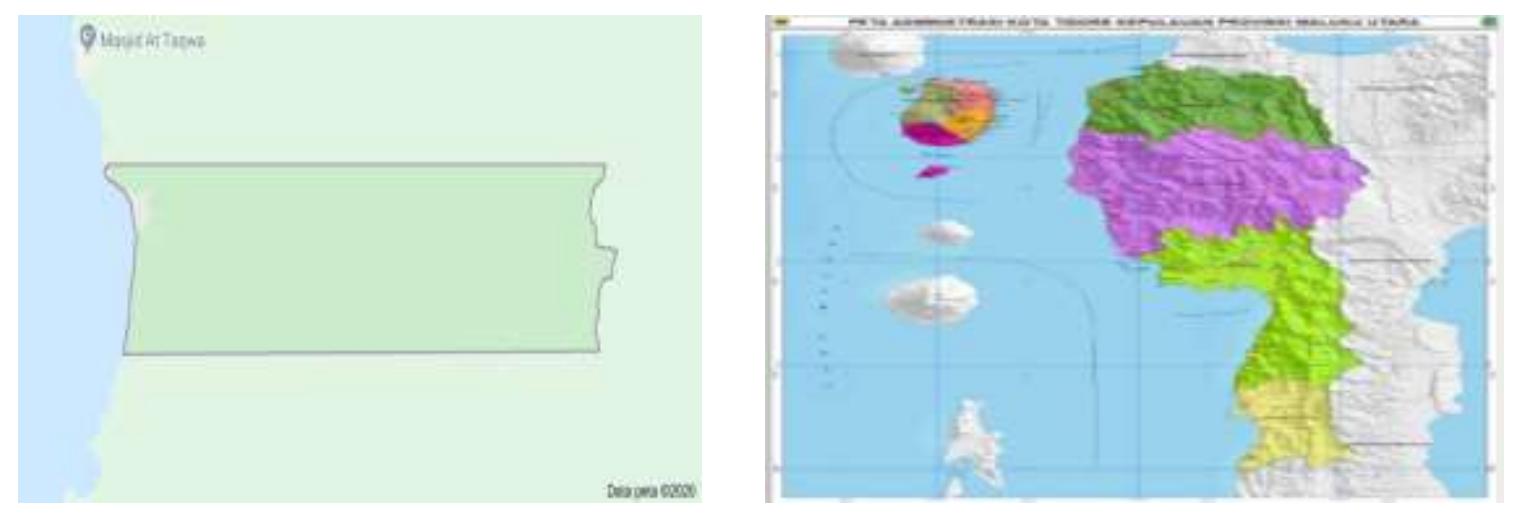

Gambar 1. Peta Desa Lifofa dan Kota Tidore Kepulauan

Secara geografis, desa Lifofa terletak di Kecamatan Oba Selatan, Kabupaten Tidore Kepulauan dengan topografi berbukit yang memiliki kandungan batuan sebagian besar batuan andesit atau hasil material vulkanik. Adapun batas wilayah desa Lifofa, Kecamatan Oba Selatan, Tidore Kepulauan adalah sebagai berikut :

a. Sebelah utara berbatasan dengan Desa Wama

b. Sebelah selatan berbatasan dengan Desa Tagalaya

c. Sebelah timur berbatasan dengan Selatan Gunung

d. Sebelah barat berbatasan dengan Laut 
Dalam tinjauan keadaan demografis Desa Lifofa, dapat dilihat beberapa data jumlah penduduk menurut beberapa klasifikasi yang penulis susun dalam beberapa tabel berikut.

Tabel 1. Jumlah Penduduk Berdasarkan Pengelompokkan Usia Dan Jenis Kelamin

\begin{tabular}{|c|c|c|c|c|c|c|}
\hline No & $\begin{array}{c}\text { Struktur } \\
\text { Usia }\end{array}$ & $\mathrm{L}$ & $\%$ & $\mathrm{P}$ & $\%$ & Total \\
\hline 1 & $0-14$ & 168 & 33,20 & 135 & 26,67 & 303 \\
\hline 2 & $15-64$ & 325 & 64,22 & 358 & 70,75 & 683 \\
\hline 3 & 64 & 13 & 2,56 & 16 & 3,16 & 29 \\
\hline \multicolumn{2}{|c|}{ Total } & 506 & 100 & 509 & 100 & 1.015 \\
\hline
\end{tabular}

Sumber: Data Profil Desa Lifofa 2018

Tabel 1 menunjukkan bahwa penduduk Desa Lifofa secara keseluruhan berjumlah 1.015 jiwa dan sebagian besar berumur antara 15-64 tahun.

Tabel 2 Jumlah Penduduk Menurut Jenis Pekerjaan

\begin{tabular}{|c|c|c|c|}
\hline No & Jenis Pekerjaan & $\mathrm{N}$ & $\%$ \\
\hline 1 & Belum Bekerja & 68 & 6,69 \\
\hline 2 & Tidak Bekerja & 25 & 2,46 \\
\hline 3 & Ibu Rumah Tangga & 80 & 7,88 \\
\hline 4 & Pelajar & 270 & 26,60 \\
\hline 5 & PNS Termasuk Guru & 27 & 2,66 \\
\hline 6 & TNI/Polri & 5 & 0,49 \\
\hline 7 & Buruh & 10 & 0,98 \\
\hline 8 & Nelayan & 7 & 0,68 \\
\hline 9 & Petani & 905 & 30,04 \\
\hline 10 & Pegawai BUMN & 1 & 0,88 \\
\hline 11 & Wiraswasta & 1015 & 100 \\
\hline 12 & Pegawai Swasta & 9,09 \\
\hline 13 & Jumlah Penduduk & 1,57 \\
\hline
\end{tabular}

Sumber: Data Profil Desa Lifofa 2018 
Tabel 2 menunjukkan bahwa penduduk Desa Lifofa secara keseluruhan berjumlah 1015 jiwa dan sebagian besar atau sebanyak 305 jiwa bekerja sebagai petani.

Tabel 3 Jumlah Penduduk Menurut Pendidikan;

\begin{tabular}{|c|c|c|c|}
\hline No & Pendidikan & $\mathrm{N}$ & $\%$ \\
\hline 1 & Belum Sekolah & 68 & 16,15 \\
\hline 2 & Belum Tamat SD (Belum Sekolah) & 97 & 23,04 \\
\hline 3 & SD & 120 & 28,50 \\
\hline 4 & SMP & 75 & 17,81 \\
\hline 5 & SMA & 47 & 11,16 \\
\hline 6 & D1 & - & - \\
\hline No & Pendidikan & N & $\%$ \\
\hline 7 & D2 & - & - \\
\hline 8 & D3 & - & - \\
\hline 9 & S1 & 2 & 2,85 \\
\hline 10 & S2 & 421 & 100 \\
\hline & Total & 2018 & \\
\hline
\end{tabular}

Sumber: Data Profil Desa Lifofa 2018

Tabel 3 menunjukkan bahwa dari jiwa, sebagian besar atau 291 jiwa belum tamat SD atau belum sekolah. Meskipun demikian, Desa Lifofa memiliki sumber daya manusia (SDM) yaitu sebanyak 33 jiwa dengan pendidikan tamatan S1 dan 2 jiwa berpendidikan tamatan S2.

\section{Ekonomi}

Di antara desa yang terdapat di Kecamatan Oba Selatan, selain Desa Wama, Desa Lifofa juga memiliki potensi alam salah satunya yang diproduksi masyarakat Desa Lifofa yaitu memproduksi Minyak Kelapa dan juga Kopra. Hasil alam tersebut telah diekspor diberbagai daerah atau mampu melayani berbagai daerah, misalnya Tidore dan berbagai daerah lainnya. Desa Lifofa juga termasuk desa yang memproduksi para pegawai dan pejabat yang berkualitas. Sehingga kehidupan ekonomi dan struktur pembangunan juga menjamin masyarakat Desa Lifofa. Namun sebagaian besar perekonomian masyarakat Desa Lifofa disokong dari hasil pertanian. 


\section{Sosial, Budaya, dan Agama}

Masyarakat Desa Lifofa merupakan masyarakat yang mayoritasnya berasal dari berbagai suku baik itu Makian, Kayoa, dan Tidore itu sendiri. Pada umumnya masyarakat tersebut sangat menghargai tradisi, adat istiadat, norma dan menjunjung tinggi nilai-nilai agama. Desa Lifofa juga memilki kondisi lingkungan yang sangat baik sehingga masyarakatnya mampu menjalin tali silaturahmi antara satu dengan yang lain. Kerukunan antar warga dijaga erat oleh tali persaudaraan sehingga tidak ada perbedaan atau saling bermusuhan antar warga.

\section{Sarana dan Prasarana}

Desa Lifofa memiliki sarana pendidikan mulai dari SD, SMP, SMA; sarana peribadatan yaitu: 1 buah Masjid, 1 buah TPQ, dan 5 buah Gereja. Sarana Pemerintahan yaitu: Kantor pemerintah Kecamatan Oba Selatan, Kantor Desa Lifofa, dan Kantor BKKBN. Sarana Kesehatan yaitu: Puskesdes. Sarana olahraga yaitu: 1 buah lapangan bola kaki dan 1 buah lapangan Bola Voli. Jadi desa Lifofa adalah sebuah desa yang masih terjaga dari nilai-nilai persaudaraan, kekeluargaan dan mulai berkembang kecintaan terhadap ilmu pengetahuan baik yang bersifat umum maupun agama.

\section{Pelaksanaan Pengabdian}

Kegiatan pengabdian yang dilakukan di Desa Lifofa terhitung tanggal 14 Maret sampai dengan tanggal 14 Mei tahun 2018, dimana sebelum dilakukan kegiatan, tim terlebih dahulu melakukan survei lokasi, pertemuan tokoh agama dan tokoh masyarakat, para pemuda dan seluruh masyarakat desa. Hasil pertemuan menuntun pada kesepakatan yaitu pembagian berdasarkan kegiatan fisik dan non fisik. Adapun kegiatannya diuraikan sebagai berikut;

\section{a. Kegiatan Fisik}

Pembuatan profil Desa Lifofa adalah salah satu program dari hasil MOU antara kampus penulis dengan BKKBN khususnya bidang kependudukan dan juga pembuatan panggung sosialisasi di Desa Lifofa. Penanggung jawab pada kegiatan ini adalah penulis dan BKKBN provinsi. Tahapan awal dalam pembuatan profil yaitu pendataan di Desa Lifofa dengan menggunakan kuesioner. Adapun isi kuisioner meliputi nama kepala keluarga, anggota keluarga, usia anggota keluarga, pendidikan, pekerjaan, penggunaan keluarga berencana $(\mathrm{KB})$, status sekolah dan tidak sekolah pada anak usia sekolah, pasangan usia subur dan pencapaian penggunaan KB pada pasangan usia subur.

Hasil pendataan digunakan sebagai laporan data kependudukan dalam bentuk profil desa. Adapun kendala yang dihadapi dalam pembuatan profil desa adalah tidak tersediannya percetakan di lokasi KKLI sehingga harus dicetak di kota Ternate, data profil tidak sama 
dengan data kependudukan desa, hal ini dikarena perpindahan masyarakat. Selain itu masyarakat memiliki tempat tinggal lebih dari satu sehingga menjadikan mereka tyidak menetap dan tidak mengurus kartu keluarga.

Selain kegiatan di atas juga membuat rumah sosialisasi agar seluruh kegiatan sosialisasi BKKBN bisa diakses oleh seluruh lapisan masyarakat. Tujuan lainnya adalah agar seluruh masyarakat dapat lebih mengerti apa yang menjadi tujuan dari BKKBN atau program KKLI.

\section{b. Kegiatan Non Fisik}

a) Pengambilan Data Primer di Desa Lifofa

Data primer diperoleh dengan dua cara yaitu :

1) Mengunakan teknik interview/wawancara terstruktur dengan bantuan kuisioner pada semua populasi yang dijadikan objek kegiatan (Indriantoro, 2002)

2) Teknik observasi terhadap kartu keluarga

Populasinya dalam kegiatan pengambilan data adalah masyarakat yang berada di Desa Lifofa, Kecamatan Oba Selatan, Kabupaten Tidore Kepulauan, yang diambil berdasarkan jumlah kepala keluarga. Kartu keluarga yang digunakan adalah kartu keluarga yangh di peroleh dari hasil pendataan dan akan dilakukan dengan cara manual.

Pengolahan data dilakukan dengan cara manual dan komputerisasi dengan tahap-tahap sebagai berikut:

1) Pemeriksaan data (Editing)

Pemeriksaan data yang menyesuaikan data, sesuai dengan apa yang diinginkan.

2) Pengkodean data (Codening)

Pemberian kode pada data, dengan mengubah kata-kata menjadi angka.

3) Pemisahan (Sorting)

Pemisahan data dengan melakukan pemindahan data untuk pengelompokan data menurut jenis yang dikehendaki (Klasifikasi Data).

4) Pembersihan Data (Cleaning)

Pembersihan data dilakukan sebelum data tersebut dianalisis dengan melihat variabelvariabel yang diteliti.

Data yang diperoleh melalui kuisioner diolah secara manual kemudian data tersebut disajikan dalam bentuk tabel frekuensi disertai dengan penjelasan secara narasi sebagai kelengkapan laporan dan sekaligus pembuatan profil Desa Lifofa 
Cara tabulasi data menggunakan rumus sebagai berikut : (Sekaran, 2012)

Persentase: $\frac{n}{N} X 100$

Keterangan :

$\mathrm{N}$ : Total Populasi

n : Jumlah Responden

Hasil pengambilan data sekunder diuraikan berdasarkan masing-masing variabel sebagai berikut :

1) Distribusi jumlah KK berdasarkan RT

Tabel 4. Distribusi Responden Jumlah KK Berdasarkan RT di Desa Lifofa, Kecamatan Oba Selatan, Kabupaten Tidore Kepulauan

\begin{tabular}{|c|c|c|}
\hline RT & $\mathbf{N}$ & $\mathbf{\%}$ \\
\hline I & 45 & 16,36 \\
\hline II & 38 & 13,81 \\
\hline III & 45 & 16,36 \\
\hline IV & 29 & 10,54 \\
\hline V & 17 & 6,18 \\
\hline VI & 35 & 12,72 \\
\hline VII & 36 & 13,09 \\
\hline VIII & 30 & 10,90 \\
\hline Total & 275 & 100 \\
\hline
\end{tabular}

(Sumber : Data Primer Tahun 2018)

Tabel 4 menunjukkan bahwa desa Lifofa terdiri dari 8 RT. Jumlah jiwa terbanyak terdapat di RT 1 dan RT 3 yaitu masing-masing sebanyak 45 jiwa atau 16,36\% . 
2) Distribusi responden berdasarkan jenis kelamin

Tabel 5. Distribusi responden berdasarkan jenis kelamin di Desa Lifofa, Kecamatan Oba Selatan, Kabupaten Tidore Kepulauan.

\begin{tabular}{|c|c|c|}
\hline Jenis Kelamin & $\mathrm{N}$ & $\%$ \\
\hline Laki-laki & 514 & 51,14 \\
\hline Perempuan & 501 & 49,85 \\
\hline Total & 1005 & 100 \\
\hline
\end{tabular}

(Sumber : Data primer Tahun 2018)

Tabel 5 menununjukkan bahwa distribusi responden ditinjau berdasarkan jenis kelamin, bahwa sebagian besar penduduk berjenis kelamin laki-laki yaitu sebanyak 514 jiwa atau $51,14 \%$.

3) Distribusi responden berdasarkan umur

Tabel 6. Distribusi responden berdasarkan pengelompokkan umur di Desa Lifofa, Kecamatan Oba Selatan, Kabupaten Tidore Kepulauan

\begin{tabular}{|c|c|c|}
\hline Umur (tahun) & $\mathrm{N}$ & $\%$ \\
\hline $0-14$ & 303 & 30,14 \\
\hline $15-64$ & 683 & 67,96 \\
\hline $65+$ & 19 & 1,89 \\
\hline Total & 1005 & 100 \\
\hline
\end{tabular}

(Sumber : Data primer Tahun 2018)

Tabel 6 menunjukkan bahwa pengelompokan umur responden, sebagian besar adalah pada umur antara 15-64 tahun yaitu sebanyak 683 jiwa $(67,96 \%)$

4) Distribusi responden berdasarkan jumlah anak usia Sekolah 7-15 tahun

Tabel 7 Distribusi responden berdasarkan jumlah anak usia sekolah7-15 tahun di Desa Lifofa, Kecamatan Oba Selatan, Kabupaten Tidore Kepulauan.

\begin{tabular}{|c|c|c|}
\hline Anak Usia Sekolah & N & $\%$ \\
\hline Sekolah & 195 & 96,53 \\
\hline Tidak sekolah & 7 & 3,46 \\
\hline Total & 202 & 100 \\
\hline
\end{tabular}

(Sumber : Data primer Tahun 2018) 
Tabel 7 menujukkan bahwa distribusi responden berdasarkan jumlah anak usia sekolah

7-15 tahun didominasi oleh anak-anak yang sekolah yaitu sebanyak 195 orang.

5) Distribusi responden berdasarkan jumlah anak usia sekolah 16-18 Tahun

Tabel 8 Distribusi responden berdasarkan jumlah anak usia sekolah 16-18 tahun di Desa Lifofa, Kecamatan Oba Selatan, Kabupaten Tidore Kepulauan.

\begin{tabular}{|c|c|c|}
\hline Anak usia sekolah & N & $\%$ \\
\hline Sekolah & 47 & 100 \\
\hline Tidak sekolah & 0 & 0 \\
\hline Total & 47 & 100 \\
\hline
\end{tabular}

(Sumber : Data primer Tahun 2018)

Tabel 8 menunjukkan bahwa distribusi Responden berdasarkan jumlah anak usia sekolah 16-18 tahun didominasi oleh anak dengan kegiatan belajar yaitu sebanyak 47 orang.

6) Distribusi responden berdasarkan peserta $\mathrm{KB}$

Tabel 9 Distribusi responden berdasarkan jumlah peserta KB di Desa Lifofa, Kecamatan Oba Selatan, Kabupaten Tidore Kepulauan

\begin{tabular}{|c|c|c|}
\hline Peserta KB & N & $\%$ \\
\hline Pil & 5 & 5,15 \\
\hline Suntik & 46 & 47,42 \\
\hline Implan & 46 & 47,42 \\
\hline Total & 97 & 100 \\
\hline
\end{tabular}

(Sumber : Data primer Tahun 2018)

Tabel 9 menunjukkan bahwa distribusi Responden berdasarkan jumlah peserta KB di Desa Lifofa, Kecamatan Oba Selatan, Kabupaten Tidore Kepulauan, sebagian besar menggunakan KB yaitu sebanyak 97 orang, 46 orang di antaranya menggunakan KB suntikan dan jumlah yang sama menggunakan KB implan. 
7) Distribusi responden berdasarkan jumlah pasangan usia subur

Tabel 10. Distribusi responden berdasarkan jumlah pasangan usia subur di Desa Lifofa, Kecamatan Oba Selatan, Tidore Kepulauan

\begin{tabular}{|c|c|c|}
\hline Pasangan usia subur & N & $\%$ \\
\hline RT.1 & 29 & 14,87 \\
\hline RT.2 & 32 & 16,41 \\
\hline RT.3 & 29 & 14,87 \\
\hline RT.4 & 18 & 9,23 \\
\hline RT.5 & 11 & 5,64 \\
\hline RT.6 & 26 & 13,33 \\
\hline RT.7 & 27 & 13,84 \\
\hline RT.8 & 23 & 11,79 \\
\hline Total & 195 & 100 \\
\hline
\end{tabular}

(Sumber : Data primer Tahun 2018)

Tabel 10 menunjukkan bahwa distribusi responden berdasarkan jumlah pasangan usia subur sebagian besar atau sebanyak 32 orang bertempat tinggal di lingkungan RT 2.

8) Distribusi responden berdasarkan pengelompokan umur istri

Tabel 11 Distribusi responden berdasarkan pengelompokkan umur istri di Desa Lifofa, Kecamatan Oba Selatan, Kabupaten Tidore Kepulauan

\begin{tabular}{|c|c|c|}
\hline Umur Istri (Tahun) & $\mathrm{N}$ & $\%$ \\
\hline $15-19$ & 1 & 0,51 \\
\hline $20-29$ & 53 & 27,17 \\
\hline $30-49$ & 141 & 72,30 \\
\hline Total & 195 & 100 \\
\hline
\end{tabular}

(Sumber : Data Primer Tahun 2018)

Tabel 11 menunjukkan distribusi responden berdasarkan pengelompokkan umur istri di Desa Lifofa berjumlah 141 orang berumur 30-49 tahun.

\section{c. Penyuluhan Tentang Kesehatan}

Kegiatan penyuluhan kesehatan dengan tema membangun kualitas reproduksi dan mental remaja indonesia. Proses penyuluhan tentang kesehatan reproduksi yang di laksanakan di 
Desa Lifofa merupakan salah satu kegiatan program non fisik di SMA Negeri 9 Tidore Kepulauan.

Tujuan kegiatan penyuluhan adalah untuk meningkatkan pengetahuan siswa SMA tentang masa remaja, dampak seks bebas, narkotika serta pengembangan skill agar menjadi remaja yang berkualitas. Kegiatan penyuluhan dilaksanakan pada hari 23 April 2018 pukul 08.30 WIT. Selanjutnya kegiatan ini dibuka oleh kordinator desa, kegiatan tersebut diisi oleh Hasna Kaplale, Amd. Kep, tentang kesehatan reproduksi. Materi yang diberikan terdiri dari definisi jenis reproduksi, tanda-tanda mengalami masa remaja, dan di lanjutkan materi kedua. Tentang pornografi, infeksi menular seksual (IMS), pendewasaan usia perkawinan (PUP) dan life skill. Adapun karakteristik responden sebagai berikut :

Tabel 12 Distribusi responden berdasarkan umur audiens di sekolah SMA Negeri 7 Tidore Kepulauan.

\begin{tabular}{|c|c|c|}
\hline Umur (Tahun) & $\mathrm{N}$ & $\mathrm{F}$ \\
\hline 15 & 5 & 7,7 \\
\hline 16 & 27 & 41,5 \\
\hline 17 & 33 & 50,8 \\
\hline Total & 65 & 100,0 \\
\hline
\end{tabular}

(Sumber : Data Primer Tahun 2018)

Tabel 12 menujukkan bahwa distribusi responden berdasarkan umur audiens di SMA Negeri 7 Tidore Kepulauan, sebagian besar atau sebanyak 33 (50,8\%) audiens berumur 17 tahun.

Tabel 13 Distribusi audiens berdasarkan Kelas di Sekolah SMA Negeri 9 Tidore Kepulauan.

\begin{tabular}{|l|c|c|}
\hline Kelas & N & F \\
\hline XI & 38 & 58,5 \\
\hline XII & 27 & 41,5 \\
\hline Total & 65 & 100,0 \\
\hline
\end{tabular}

(Sumber : Data Primer Tahun 2018)

Tabel 13 menunjukkan bahwa distribusi audiens berdasarkan kelas di sekolah SMA Negeri 7 Tidore Kepulauan dengan jumlah siswa kelas XI sebanyak 38 siswa atau 58,5\% dan kelas XXI sebanyak 27 siswa atau 41,5\%. Total siswa secara keseluruhan sebanyak 65 siswa atau $100 \%$. 
Tabel 14 distribusi audiens berdasarkan alamat siswa di Sekolah SMA Negeri 9 Tidore Kepulauan.

\begin{tabular}{|l|c|c|}
\hline \multicolumn{1}{|c|}{ Alamat } & N & F \\
\hline Nuku & 6 & 9,23 \\
\hline Tagalaya & 18 & 27,69 \\
\hline Lifofa & 29 & 44,61 \\
\hline Wama & 12 & 18,46 \\
\hline & 65 & 100,0 \\
\hline
\end{tabular}

(Sumber : Data Primer Tahun 2018)

Tabel 14 menunjukkan bahwa distribusi audiens berdasarkan alamat siswa di sekolah SMA Negeri 9 Tidore Kepulauan, sebagian besar atau sebanyak Perempuan audiens berasal dari Desa Lifofa. dan sebagian kecil atau Laki-Laki audiens berasal dari Desa Lifofa.

\section{d. Pengajaran di Sekolah Desa Lifofa}

Pengajaran di sekolah Desa Lifofa dilakukan sesuai dengan basis keilmuan. Tahapan dan tahapan awal mengajar pada tanggal 23 Maret - 13 Mei 2018 di semua kelas mulai pukul 08:00-12.00 untuk SD dan SMP dan SMA disesuaikan dengan Mata pelajaran yang diberikan yaitu Maematika, Biologi, PAI, PPKN, Kerajinan Tangan dan Akhlaq.

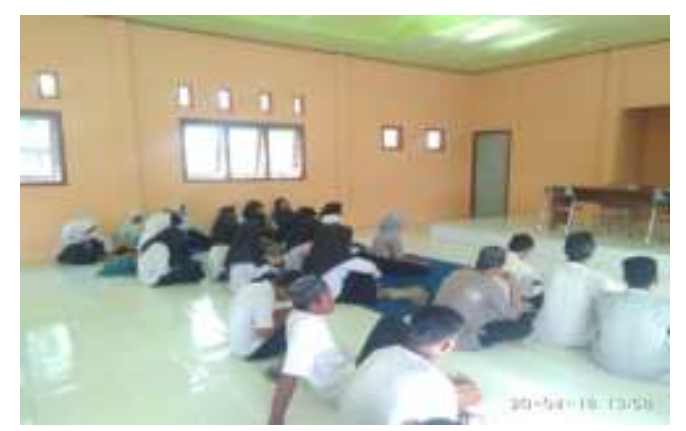

Gambar.1: Kegiatan belajar mengajar

Adapun beberapa program kerja pengabdian dalam rangka membangun kebersamaan sosial dan keagamaan yang penulis cantumkan dalam tabel di bawah ini; 
Tabel 15. Program kegiatan kesadaran sosial dan pembimbingan keagamaan pada masyarakat Desa Lifofa.

\begin{tabular}{|c|c|}
\hline No & Program kerja Fisik \\
\hline 1 & Melaksanakan bakti/pembersihan dikuburan dan Masjid \\
\hline 2 & Melaksanakan bakti/pembersihan dilingkungan Desa Lifofa \\
\hline 3 & $\begin{array}{c}\text { Pembuatan papan nama pemerintah Desa Dan Tapal Batas RT, RW, dan } \\
\text { Dusun Desa Lifofa }\end{array}$ \\
\hline 4 & Pembuatan papan Nama Kepala Keluarga di tiap-tiap rumah di Desa Lifofa \\
\hline 5 & $\begin{array}{c}\text { Melaksanakan pembinaan masyarakat yakni di TPQ, Majelis Taklim dan } \\
\text { Anak-anak }\end{array}$ \\
\hline 6 & $\begin{array}{c}\text { Melaksanakan kegiatan pentas seni budaya dilangsungkan dengan perayaan } \\
\text { ISRA MI'RAJ }\end{array}$ \\
\hline 7 & Melaksanakan pertandingan sepak bola gawang sedang di Desa Lifofa \\
\hline
\end{tabular}

Program kerja yang direncanakan dapat terealisasi dengan baik karena atas dukungan dan kerja sama masyarakat Desa Lifofa khususnya pemuda Desa Lifofa Adapun Pentas Seni Budaya dan Olahraga, yaitu:

1) Hafalan Qur'an

2) Tilawatil Qur'an

3) Puisi

4) Busana Muslim

5) Qasida Rabana

6) Samra/Tarian Daerah

7) Teater

8) Sepak Bola Gawang Sedang

Kegiatan yang dilakukan merupakan tujuan untuk membangun tali silaturahmi, pembinaan akhlak dan prilaku terhadap masyarakan khususnya anak-anak, Pemuda Dan Lain-lain. Karena banyak hal yang menjadi gambaran buat penulis sebagai, bahwa pada umumnya masih terdapat berbagai bentuk penyimpangan yang dilakukan sebagian masyarakat dalam bentuk kepercayaan kepada Tuhan Yang Maha Esa, hubungan tali silaturahmi. Sehingga bentuk pembinaan ke arah yang lebih baik menjadi prioritas utama. Pembinaan generasi muda yang lebih baik yang diawali dengan pembinaan remaja bahwa persatuan dan kesatuan dalam suatu Desa adalah lebih baik. Hal ini dilakukan sebagai bentuk pengabdian juga kepada masyarakat. 


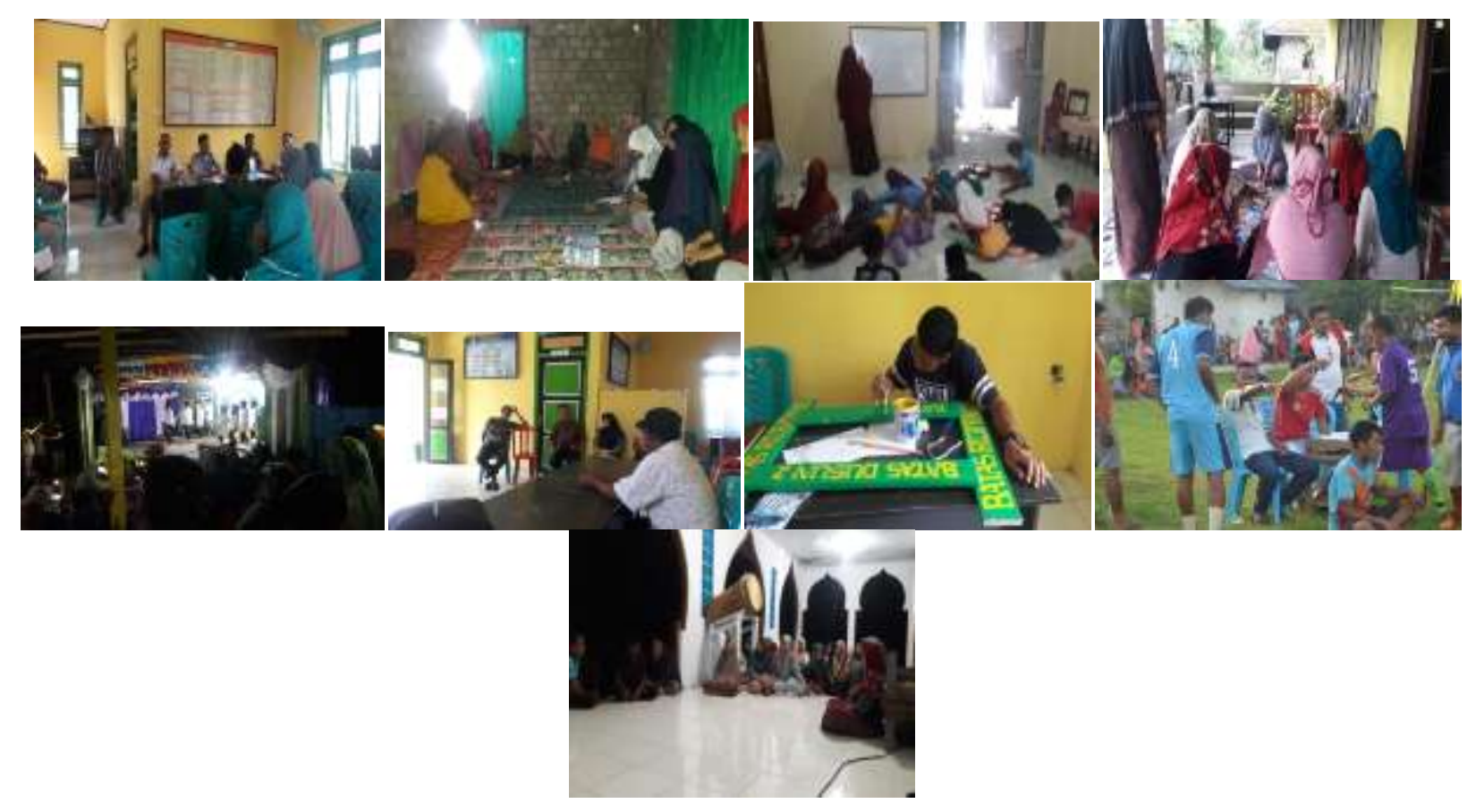

Gambar, 2: Potret kegiatan pengabdian yang sedang berlangsung

\section{Kesimpulan}

Berdasarkan hasil kegiatan, pengamatan, maupun pelaksanaan kegiatan pengabdian yang telah direncanakan, disusun dan dilaksanakan. Maka penulis merumuskan beberapa kesimpulan dimulai dari kegiatan fisik yang dilakukan meliputi pembuatan profil desa dan pembuatan rumah sosialisasi. sedangkan kegiatan non fisik meliputi pengambilan data primer di Desa Lifofa, penyuluhan tentang kesehatan, dan pengajaran di sekolah dasar Desa Lifofa.

Keberhasilan kegiatan ini tidak lepas dari kerja sama antara perangkat desa, masyarakat, serta semua pihak yang membantu dan mendukung terlaksananya kegiatan ini, tanpa adanya kerja sama yang baik, kegiatan tidak akan berjalan dengan lancar. Dengan adanya kegiatan pengabdian ini juga, para masyarakat mencoba mencontoh cara berfikir mahasiswa untuk befikir modern dengan mengembangkan sumber daya mereka, kehadiran mahasiswa juga agar masyarakat terbantu dengan bertambahnya informasi dan ilmu pengetahuan.

Selain itu, penulis dapat memperoleh ilmu belajar cara hidup dari orang desa seperti gotong royong ramah dan saling tolong menolong. Karena teori yang didapat pada bangku kuliah tidak semua sesuai dengan situasi dan kondisi lapangan, maka dari itu pengabdian ini merupakan jalan untuk menambah pengetahuan lapangan bagi penulis. 


\section{Pernyataan}

Artikel ini merupakan laporan pengabdian kepada masyarakat yang dilaksanakan oleh mahasiswa IAIN Ternate. Penulis ucapkan terima kasih kepada pemerintah desa maupun kecamatan yang telah mengizinkan penulis untuk melaksanakan kegiatan pengabdian, serta kepada para masyarakat dan pemuda-pemudi desa Lifofa yang telah meluangkan waktu dan tenaga untuk membantu penulis dalam melaksanakan segala kegiatan hingga sukses.

\section{Daftar Pustaka}

Afrilita, Nur, 2013, "Analisis SWOT dalam Menentukan Strategi Pemasaran Sepeda Motor Pada PT. Samekarindo Indah di Samaranda", Jurnal Administrasi Bisnis, Vol. 1, Vol. 1, Maret

Supomo, Bambang dan Nur Indriantoro. 2002, Metodologi Penelitian Bisnis, Cetakan Kedua, Yogyakara: BFEE UGM.

Direktorat Pembinaan Penelitian dan Pemberdayaan Masyarakat., 2007, Pengetahuan dasar KKN. Jakarta: Universitas Indonesia.

Rangkuti, Freddy, 2003, Analisis SWOT Teknik Membedah Kasus Bisnis, Jakarta : Gramedia Pustaka Utama.

Hunger, K., 2003, Industrial Dyes: Chemistry, Properties, Applications, Cambridge : Wiley-VCH, Weinheim.

Data Desa Lifofa, (2018), Laporan Profil Desa Tingkat Desa dan Kelurahan

LP2M IAIN Ternate, (2017), Buku Panduan Kuliah Kerja Integratif, Ternate : IAIN Ternate. 